\title{
EVALUATION OF THE RESULTS OF PELVIC FIXATION IN LONG LUMBOSACRAL INSTRUMENTATIONS IN ELDERLY PATIENTS
}

\author{
AVALIAÇÃO DOS RESULTADOS DA FIXAÇÃO PÉLVICA EM LONGAS INSTRUMENTAÇÕES \\ LOMBOSSACRAS EM PACIENTES IDOSOS
}

\section{EVALUACIÓN DE LOS RESULTADOS DE LA FIJACIÓN PÉLVICA EN INSTRUMENTACIONES LUMBOSACRAS LARGAS EN PACIENTES MAYORES}

\author{
Marcos Calixto Acchar ${ }^{1,2}$, Leonardo Fonseca Rodrigues ${ }^{2}$, Carlos Alexandre Botelho do Amaral ${ }^{3}$, Sergio Gurgel Fernandes ${ }^{1,2}$, Flavio Cavallari ${ }^{2}$ \\ 1. Universidade Federal do Rio de Janeiro/HUCFF, Rio de Janeiro, RJ, Brazil. \\ 2. Hospital São Vicente de Paulo, Rio de Janeiro, RJ, Brazil. \\ 3. Hospital Santa Teresa, Petrópolis, RJ, Brazil.
}

\begin{abstract}
Objective: Evaluate the initial results and the possible complications of the combination of pelvic fixation using iliac screws in long instrumentations of the lumbar spine in elderly patients. Methods: An analysis of 38 patients who underwent lumbar spine arthrodesis instrumentation with more than 3 levels, in which we included level L5-S1 and extended the fixation to the iliac crest. Radiological assessment of instrumentation through X-ray of the lumbar spine and pelvis, and computed tomography, to investigate the presence of radiological fusion. Clinical evaluation through a questionnaire of buttock pain including the visual analogue pain score (VAS). Complications related to pelvic instrumentation were investigated. Results: All patients had radiological fusion in the lumbosacral transition. A halo was found around the iliac screw on imaging studies in $31 \%$ of patients, but without related symptoms. The questionnaire of buttock pain found that $15 \%$ of patients had some low intensity buttock pain (VAS 1-2) and no need to or interest in removing the screws. There was infection at the surgical site in $2 \%$ of cases, hematoma in the buttocks in $5 \%$, and vertebral body fracture in the cranial level instrumented in $7 \%$ of cases. Conclusions: Pelvic fixation through the iliac screws proved to be effective in protecting the S1 screws in long instrumentations including the L5-S1 level in elderly patients, allowing the radiological bone fusion. The overall results for pain were satisfactory, based on a questionnaire of buttock pain. There are no signs of overload or degeneration of the sacroiliac joints in the early years after surgery. Level of Evidence IV; Case series - therapeutic study.
\end{abstract}

Keywords: Arthrodesis; llium; Outcome assessment; Lumbosacral region.

\section{RESUMO}

Objetivo: Avaliar os resultados iniciais e as possíveis complicações da combinação da fixação pélvica através dos parafusos nos ilíacos nas instrumentações longas da coluna lombar em pacientes idosos. Métodos: Análise de 38 pacientes, submetidos a artrodese da coluna lombar com instrumentação maior que três níveis, incluímos o nível L5-S1 e estendemos a fixação ao ilíaco. Avaliação radiológica da instrumentação, através de radiografia da coluna lombar e da bacia, e tomografia computadorizada, pesquisando-se presença de fusão radiológica. Avaliação clínica através de questionário sobre dor glútea, incluindo o escore visual analógico de dor (VAS). Foram pesquisadas complicações relacionadas a instrumentação pélvica. Resultados: Todos os pacientes possuíam fusão radiológica na transição lombossacra. Foi encontrado halo ao redor do parafuso ilíaco nos exames de imagem de 31\% dos pacientes, porém sem sintomas relacionados. O questionário sobre dor glútea identificou que 15\% dos pacientes possuíam alguma dor glútea de baixa intensidade (VAS 1 a 2) e sem necessidade ou interesse de retirar os parafusos. Houve infecção em sitio cirúrgico em $2 \%$ dos casos, hematoma em região glútea em $5 \%$ e fratura do corpo vertebral no nível mais cranialmente instrumentado em $7 \%$ dos casos. Conclusão: A fixação pélvica, através de parafusos ilíacos, mostrou-se eficaz na proteção dos parafusos de S1 em instrumentações longas, que incluam o nível L5-S1 em pacientes idosos, permitindo a fusão óssea radiológica. Os resultados gerais de dor foram satisfatórios com base em um questionário sobre dor glútea. Não há sinais de sobrecarga ou degeneração das articulações sacro-ilíacas nos primeiros anos após a cirurgia. Nível de Evidência IV; Estudo terapêutico - série de casos.

Descritores: Artrodese; llio; Avaliação de resultados; Região lombossacral

\section{RESUMEN}

Objetivo: Evaluar los resultados iniciales y las posibles complicaciones de la combinación de la fijación pélvica con tornillos en los ilíacos en las instrumentaciones largas de la columna lumbar en pacientes ancianos. Métodos: Análisis de 38 pacientes sometidos a la artrodesis de la columna lumbar con instrumentación de más que tres niveles cuando se incluyó L5-S1 y se extendió la fijación al ilíaco. Evaluación radiológica de la instrumentación de la columna lumbar y cadera y tomografía computarizada para investigar la presencia de fusión radiológica. Evaluación clínica con cuestionario sobre dolor glúteo, incluyendo la Escala Visual Analógica (EVA). Se han investigado las complicaciones relacionados con la instrumentación pélvica. Resultados: Todos los pacientes tenían fusión radiológica en la transición lumbosacra. Se encontró halo radiológico alrededor del tornillo ilíaco en los estudios de imagen del 31\% de los pacientes, pero sin síntomas 
relacionados. El cuestionario sobre el dolor glúteo identificó que el 15\% de los pacientes tenían algún dolor de baja intensidad (EVA 1-2) y no había necesidad o interés en retirar los tornillos. Se produjo una infección en el sitio quirúrgico en $2 \%$ de los casos, hematoma en la región glútea en un 5\% y fractura del cuerpo vertebral en el nivel más craneal de instrumentación en el 7\% de los casos. Conclusiones: La fijación de la pelvis a través de tornillos en ilíacos se mostró eficaz en la protección de los tornillos de S1 en instrumentaciones largas que incluyan el nivel L5-S1 en pacientes ancianos, permitiendo la fusión ósea radiológica. Los resultados generales del dolor fueron satisfactorios sobre la base de un cuestionario sobre el dolor glúteo. No hay signos de sobrecarga o degeneración de las articulaciones sacroilíacas en los primeros años después de la cirugía. Nivel de Evidencia IV; Estudio terapéutico - Serie de casos.

Descriptores: Artrodesis; Ilion; Evaluación de resultados; Región lumbosacra.

\section{INTRODUCTION}

The number of spine surgeries to treat deformities and degenerative pathologies in elderly patients has increased with the aging of the population, and is accompanied by advances in surgical techniques. The concern with complications is also growing, especially when the procedure involves long instrumentations that include L5-S1 in elderly patients, due to osteoporosis and the biomechanical forces that act on the lumbosacral transition. ${ }^{1,-4}$

Studies have shown high rates of pseudoarthrosis in L5-S1 and complications with the screw in S1 in multiple-level instrumentations ending caudally at $S 1 .{ }^{1,2,5,6}$ There is also concern about degeneration of the sacroiliac joint after long arthrodeses involving the lumbar spine. ${ }^{7-10}$

A possible solution to these problems was to extend the fixation as far as the hip, which can be done using various techniques. This gives screws in S1 more protection, reducing potential complications related to $L 5-S 1.9,11-13$

Among the forms of fixation, the use of screws in the iliac crests has the advantage of providing a fixation with biomechanical advantages, due to the length of the screw, and its divergent positioning, maintaining the sacral screws and connecting the iliac screws to the same rod. $2,5,14$

However, questions have been raised regarding lumbar-pelvic fixation, mainly due to complications related to the placement of the screws, the fact that they may bulge out, and the need to remove them. ${ }^{13,15,16}$

The aim of this work was to evaluate our initial results and the possible complications of the combination of pelvic fixation using screws in the iliac crests for long instrumentations of the lumbar spine in elderly patients.

\section{METHODS}

This study included 38 patients who underwent a surgical procedure for lumbar spine arthrodesis with an approach of more than three levels, all including L5-S1 and pelvic fixation with screws in the iliac crest. (Table 1) The surgeries were performed in the period from 2011 to 2015 , by the same group of four surgeons. The patients included 12 men and 26 women, with a mean age of 75 years (ranging from 65 to 84 years). The indications for multi-segment arthrodesis included: accentuated degenerative scoliosis with clinical and radiological progression, stenosis of the vertebral canal, multi-segment instability, disease of the adjacent level, and pseudoarthrosis following previous surgery. (Table 2) The mean follow-up period was 28 months (ranging from 13 to 51 months). Because this is a retrospective evaluation study, it was not submitted to the Ethics Committee, and there was no signing of an informed consent form.

Table 1. Levels of instrumentation of patients in the study.

\begin{tabular}{c|c}
\hline Extent of the fixation & Number of cases \\
\hline T4-S1 + ilium & 2 \\
\hline T10-S1 + ilium & 5 \\
\hline T11-S1 + ilium & 2 \\
\hline T12-S1 + ilium & 10 \\
\hline L1-S1 + ilium & 2 \\
\hline L2-S1 + ilium & 17 \\
\hline
\end{tabular}

All the patients were submitted to posterolateral arthrodesis with instrumentation through polyaxial pedicle screws in the lumbar spine. Interbody spaces were not used on any of the patients included in the study. An autologous graft was used in all cases, and no use was made of bone morphogenetic protein.

For the placement of the screws in the iliac crests, a distal and lateral dissection was performed as far as the iliac crest, by the same approach through the lumbosacral spine, looking for the posterosuperior iliac spine (PSIS). The point of entry of the iliac screw was $1 \mathrm{~cm}$ caudal to the lower palpated lobe of PSIS and $1 \mathrm{~cm}$ below the superficial crest of the PSIS. (Figure 1) Before completing the approach, a small amount of cortical bone was removed from the bed where the screw head was to be inserted, using bone rongeur forceps, to enable better accommodation of the screw. The pedicle screw probe was then placed at the point of entry, and directed towards the anteroinferior iliac spine. The pedicle probe was gradually advanced, until it reached the target bone, just above the sciatic notch (SN), avoiding penetrating the $\mathrm{SN}$, which could cause injury to the upper gluteal vessels and sciatic nerve. (Figure 2) In the authors' experience, digital palpation of the ipsilateral greater trochanter is effective, as a good parameter for cranial-caudal angulation of the pedicle probe, and the inclination of the external ilium plate is used to evaluate the divergence needed to make the approach. After completing the approach into which the screw was to be inserted, a pedicle probe was used to check the walls of the bone tunnel made in the ilium. The length of the screw was measured with a millimeter graduated pedicle probe or with the pedicle probe itself. Fluoroscopy was used routinely to ensure that there was no invasion of SN. Subsequently, the iliac screw was inserted so that the screw head was inserted deep inside the PSIS, to prevent the patient from feeling a bulge. The screws were connected to the longitudinal rod directly or using lateral connectors fixed to the

Table 2. Main pathologies in operated patients.

\begin{tabular}{c|c}
\hline Surgical indication & Number of cases \\
\hline Accentuated degenerative scoliosis & 5 \\
\hline Stenosis of the vertebral canal & 18 \\
\hline Multi-segment instability & 5 \\
\hline Disease of the adjacent level & 8 \\
\hline Pseudoarthrosis after previous surgery & 2 \\
\hline
\end{tabular}

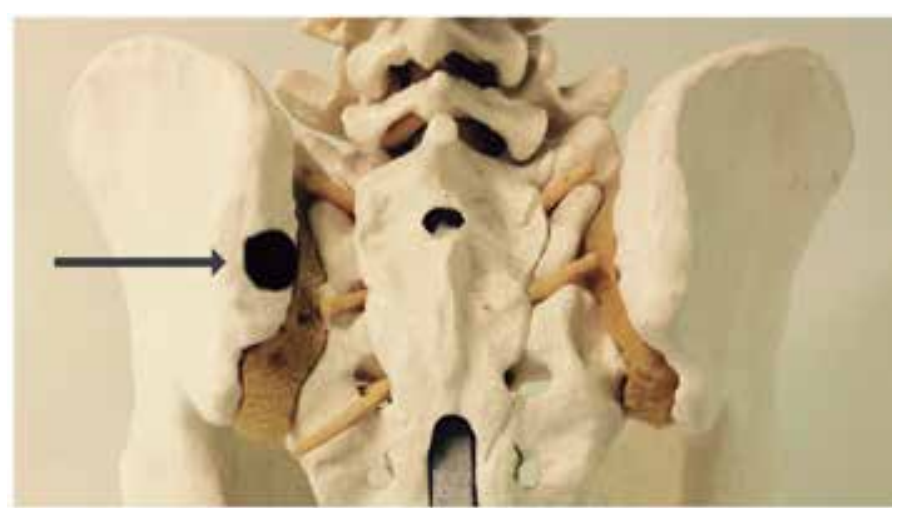

Figure 1. Model of the hip showing the point of entry of the screw in the posterior view. 
heads of the iliac crews, depending on their alignment in relation to the pedicle screws. Generally, the use of the lateral connector was necessary. The diameter of the iliac screws was 6.0 to 7.5 millimeters $(\mathrm{mm})$ and the length ranged from 60 to $80 \mathrm{~mm}$. The SN screws were 6 to $6.5 \mathrm{~mm}$ in diameter, with a length of 35 to $45 \mathrm{~mm}$. A bicortical fixation was always sought.

The patients were routinely referred for physiotherapy, and mobilized on day 1 after surgery, when they were instructed to stand, and walk beside the bed. The standard protocol included early ambulation, soon after leaving the intensive care unit. No preoperative braces were used in these patients.

For the radiological assessment, AP and lateral radiographs of the lumbar spine and AP of the hip were used, as well as computed tomography whenever a change was suspected in the radiograph. (Figures 3 and 4) Bone fusion was evaluated using the criteria reported by Kuklo et al. ${ }^{7}$

The presence of buttock pain was assessed, as a possible reported complication related to the placement of screws in the iliac crests, using questions about buttock pain/discomfort, quantification of pain by the VAS scores (0-10), and questions about bulging of the screws and the need to remove them. (Figure 5)

Possible complications related to the surgical procedure were also investigated, such as neurological deficit, postoperative infection, hematoma at the surgical site, loosening, loosening or breakage of the screws and rods, and the presence of a halo around the iliac screws.

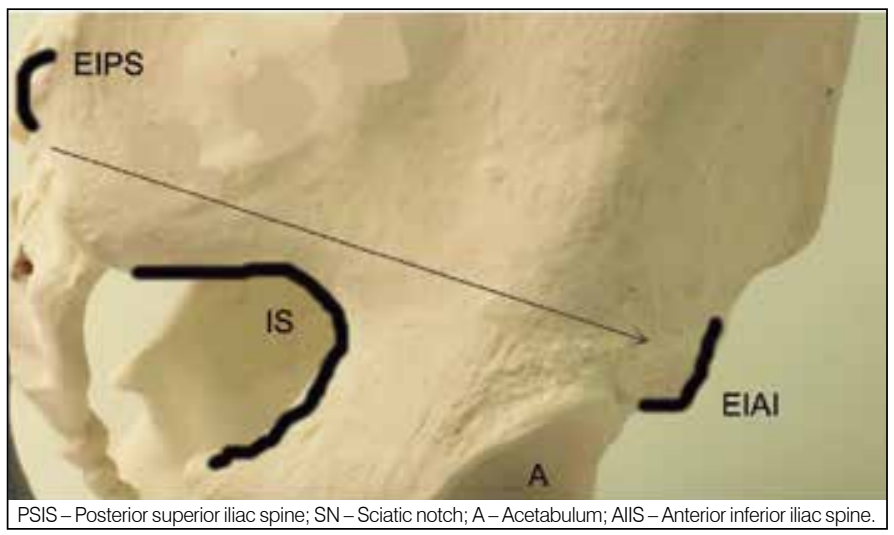

Figure 2. Model of the hip showing path of the fuse (long arrow) in the lateral view.

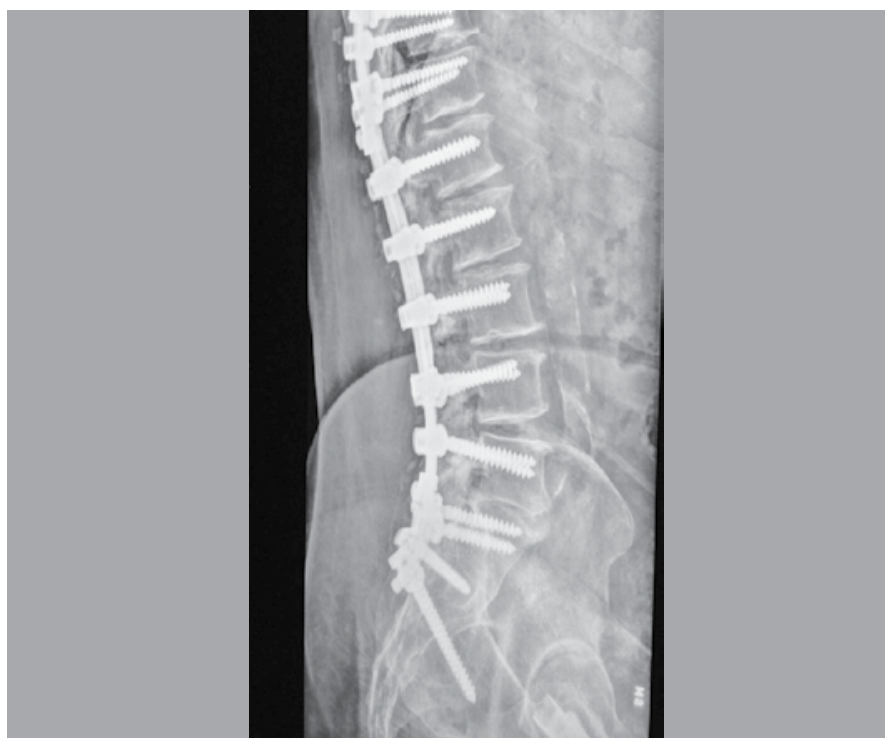

Figure 3. Postoperative view of long instrumentation with iliac fixation. Lateral radiograph.

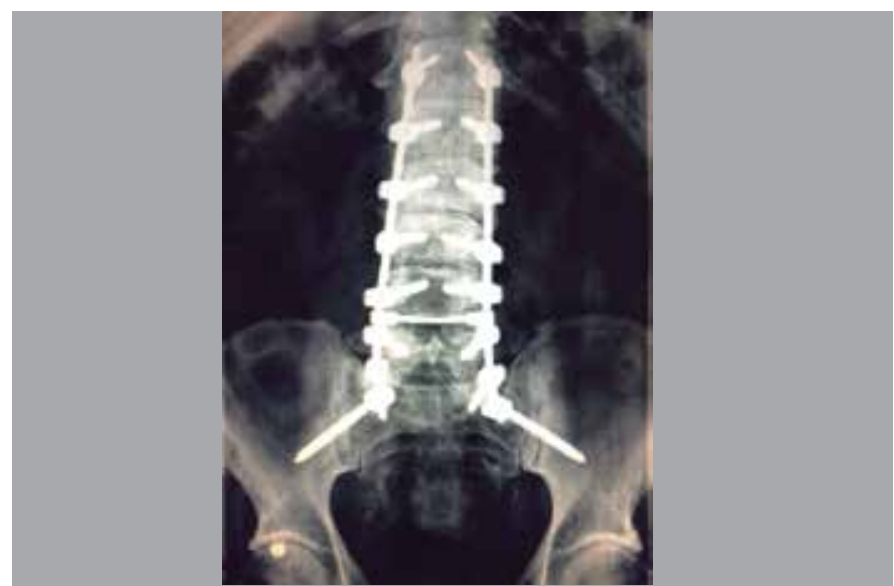

Figure 4. Postoperative view of long instrumentation with iliac fixation. Radiograph in AP lliac screws connected directly to the rods.

1. Do you have pain the buttock region?

( ) Yes ( ) No

2. On a scale of 0 to 10 , with 0 being no pain and 10 a lot of pain, indicate the level of pain that you feel regularly in the buttock region.

3. Do you feel the screws bulging out in your buttock region

( ) Yes ( ) No

4. If you feel them, does it bother you?

( ) Yes ( ) No

5. Would you like to have these screws removed due to the buttock pain? ( ) Yes ( ) No

Figure 5. Questionnaire about buttock pain.

\section{RESULTS}

We did not identify signs of failure in the sacral instrumentation in any of these patients (halo around the screw, loosening or breaking of the screw and rod, or fracture of the sacrum). There were also no breakages or loosening of the iliac fixation screws. A halo of less than $2 \mathrm{~mm}$ was found around the iliac screw in $31 \%$ $(12 / 38)$ of the cases, but without related symptoms. There were no cases of pseudoarthrosis in L5-S1, but it should be noted that $5 \%$ $(2 / 38)$ of the patients included in the study had prior symptomatic pseudoarthrosis in L5-S1 and improved after pelvic fixation and review revision of the arthrodesis. Also in the radiological evaluation, no signs of degeneration of the sacroiliac articulation were found during our follow-up. (Figure 6)

The buttock pain was not a predominant symptom in the patient follow-up. Low intensity pain (VAS $=1$ to 2 ) was identified in $15 \%(6 / 38)$ of the patients. None of those who had some residual discomfort had a halo around the iliac screws. None of the patients complained of screws bulging out underneath the skin, or showed interest in having the screws in the iliac crest removed.

There was a deep infection of the surgical wound in $2 \%(1 / 38)$ of the cases, which was resolved with surgical debridement and intravenous antibiotic therapy, not requiring removal of the implants. Five percent (2/38) of the patients had a hematoma in the buttock region, which resolved spontaneously within 2 to 3 weeks and $7 \%$ $(3 / 38)$ of the patients needed another surgical procedure to treat the vertebral fracture with more cranial instrumentation, a fact that occurred more than 3 months after the surgery. All the patients had accentuated osteoporosis, were aged over 75 years, and were treated with cranial extension of the instrumentation. There were no cases of neurological complications in the study patients. (Table 3) 


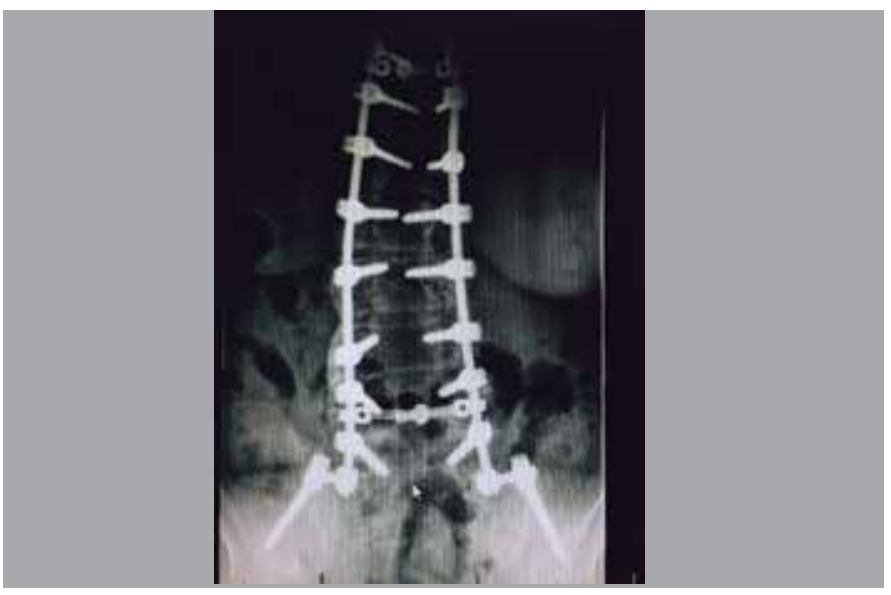

Figure 6. Postoperative - Long instrumentation with iliac screws connected to the rods through lateral connectors. Bone mass showing posterolateral fusion.

Table 3. Complications in the study patients.

\begin{tabular}{c|c}
\hline Buttock pain & $(15 \%) 6 / 38$ \\
\hline Halo $<2 \mathrm{~mm}$ around the iliac screws & $(31 \%) 15 / 38$ \\
\hline Breakage or loosening of the implants & None \\
\hline Infection & $(2 \%) 1 / 38$ \\
\hline Hematoma & $(5 \%) 2 / 38$ \\
\hline Neurological defect & None \\
\hline Fracture of the vertebra & $(7 \%) 3 / 38$ \\
\hline
\end{tabular}

\section{DISCUSSION}

Long instrumentations in the lumbar spine are sometimes necessary to treat deformities and degenerative pathologies in the lumbar spine. The pseudoarthrosis rates are high, especially for level L5-S1, and increase the more levels are instrumented. In previous studies, Kornblatt et al. report rates of 3.5 to $10 \%$ pseudoarthrosis in 1-level surgeries (L5-S1), 15-20\% in 2-level surgeries (L4-S1), and 25-33\% in 3-level surgeries (L3-S1). Olgivie and Schendel report rates of pseudoarthrosis of up to $72 \%$ in long instruments as far as the sacrum for the treatment of scoliosis. ${ }^{1.2}$

The lumbosacral transition has a high mechanical demand, and fixation of the sacrum with pedicle screws in S1 has presented high failure rates when associated with long instrumentations. It is important to note that sacral pedicle screws typically have a large diameter, and the sacrum is filled with spongy bone. This anatomical characteristic may limit the surgeon's ability to achieve good fixation of the S1 screw. The placement of bicortical screws in S1, and the use of interbody spaces, appears to reduce the rate of complications, but these rates are still high, especially in elderly patients, due to the higher incidence of osteoporosis. ${ }^{2-4.6}$

Owing to the high complication rates reported, spine instrumentation systems and surgical techniques have developed rapidly in the last two decades. ${ }^{1.2}$

McCord et al tested ten different lumbosacral constructions in a calf model, and identified that the maximum failure time was significantly higher for the models in which the fixation was extended up to the ilium. ${ }^{3}$

Fixation with iliac screw is an advance, following the development of the technique of Luque-Galveston, as it reduces the work of modeling for adaptation of the rod during surgery, and enables the use of sacral screws, connecting the iliac screws through lateral connectors on the same rod. ${ }^{5.14}$

Kuklo et al. reported a fusion rate of $95.1 \%$ in a large series of 81 patients with a long fusion of the sacrum including fixation in the iliac crests. ${ }^{7}$ Tsuchiya et al reported a fusion rate of $92.5 \%$ with a minimum follow-up of 5 years. ${ }^{17}$ In our series, posterolateral radiographic fusion through the lumbosacral junction was achieved in all 38 patients with long instrumentation up to the iliac crest; two of these patients had undergone surgery to the lumbar spine previously, and had symptomatic pseudoarthrosis. Although the number of patients included in our study is smaller, the fusion rate was better than expected.

The placement of iliac screws is a procedure that potentially increases surgical morbidity, as the technique requires greater exposure of the surgical site, but the complications were not as high as one might expect. In our series, we had no case of massive hemorrhage or any accidental damage to the large blood vessels. There were two cases of hematoma of the buttocks after surgery, which were attributed to the partial removal of the gluteal muscles to insert screws in the iliac crest. The infection rate associated solely with the iliac fixation is difficult to determine from the literature, because iliac fixation is performed together with other procedures. However, in a two-year follow-up study of patients treated with iliac fixation, Kuklo et al. reported an infection rate of $4 \%$ (3 of 81 patients). ${ }^{1}$ These authors also observed loosening of the iliac screw in three patients who had been operated for spondylolisthesis. However, there was no pseudoarthrosis in these cases. In our series, one patient had a deep wound infection which was treated successfully with surgical debridement and intravenous antibiotic therapy. Three patients had a fracture of the vertebra instrumented more cranially three months after surgery. However this was not a complication related only to iliac instrumentation, but also to osteoporosis in the elderly. Both complications were resolved with cranial extension of the instrumentation.

Other complications associated with iliac screw fixation include the development of halos (or the "windscreen-wiper" effect), injury to structures in the sciatic notch, acetabular violation, and bulging of the screws under the skin. Halos around the iliac screws have been reported quite often, but they seem to have no effect on the outcome of a solid lumbosacral fusion). In fact, halos around the iliac screws are only a radiographic finding indicating micro-movements around the screw due to the small amount of mobility that exists in the sacroiliac articulations that have not been fused.7,10,17 In this series, we observed the occurrence of a $<2 \mathrm{~mm}$ halo around the iliac screws in the imaging exams of 12 of the 38 patients who had radiographic fusion through the lumbosacral junction. In these cases, the iliac fixation was used as a temporary structural adjuvant until the lumbosacral fusion could develop. This was not a cause of residual pain, since none of the patients who had a halo $<2 \mathrm{~mm}$ in the iliac screws complained of gluteal pain. Injury to the sciatic notch structures (especially the superior gluteal artery and sciatic nerve) during insertion of the iliac screw and rods is rare, and was not reported in large series. In our series, also were also no such cases. The risk of violating the acetabulum or sciatic notch can be minimized by directing the bolts towards the anteroinferior iliac spine, and with perioperative radiological control. Bulging of the screws is an important concern, especially in patients with low weight. In a series of 36 patients with the screw fixation in the iliac crest, it was necessary to remove the screw in 8 cases. In our series, no patient complained of bulging of the screws, or requested their removal. Tumialan et al. reported that they were able to prevent this bulging in the majority of cases by burying the screw heads in the PSIS. ${ }^{18}$ We attribute the absence of complaints of screw bulging in our study due to the care taken in the technique, with the due preparation of the iliac bone, removing bone to create room for the screw head and inserting the head into the PSIS, and also to the fact that our study did not include any children, a group that tends to be more symptomatic due to the smaller body structure.

The evaluation of pain in the buttock region, using the pain score (VAS), was also satisfactory. There is no perfect way to clinically isolate the assessment of pain in the sacroiliac joint. We attempted to perform this assessment using the VAS, and radiologically by X-rays of the hip in AP (Ferguson). Of the study patients, 6 had pain or discomfort in the buttock region quantified as a VAS of 1 or 2; these values were considered low, and were very small in number more than 1 year after surgery. In parallel, in the X-rays, no radiological changes were identified that would indicate degeneration of the sacroiliac articulations during the follow-up of these patients. However, we know that 1 to 4 years may still be a short period for this evaluation. 


\section{CONCLUSIONS}

Pelvic fixation using iliac screws is a safe technique, which proved to be effective in protecting the S1 screws in long instrumentations of the spine that include level L5-S1 in elderly patients, allowing lumbosacral bone fusion. The general results for pain were satisfactory, based on a questionnaire on buttock pain. There are signs of overload or degeneration of the joints sacroiliac articulations in the first years after surgery. The results are encouraging, which leads us to continue using this technique in appropriately selected patients.

All authors declare no potential conflict of interest related to this article.

CONTRIBUTION OF THE AUTHORS: Each author made significant individual contributions to this manuscript. MCA (0000-0003-1151-734X)* was the main contributor to the writing of the manuscript. MCA, LFR (0000-0002-3583-6452)*, CABA (0000-0003-4865-2828** SGF (0000-0003-2068-8634)* and FC (0000-0002-2581-5316)* performed the surgeries, followed up patients, and gathered clinical data. MCA and LFR performed bibliographic research. FC, SGF and CABA revised the manuscript and contributed to the intellectual concept of the study. *ORCID (Open Researcher and Contributor ID).

\section{REFERENCES}

1. Kornblatt MD, Casey MP, Jacobs RR. Internal Fixation of the Lumbosacral spine fusion. A biomechanical and clinical study. Clin Orthop Relat Res. 1986:(203):141-50.

2. Ogilvie JW, Shendel M. Comparison of lumbosacral fixation devices. Clin Orthop Relat Res. 1986;(203):120-5.

3. McCord DH, Cuningham BW, Shono Y, Meyers JJ, McAfee PC. Biomechanical analysis of lumbosacral fixation. Spine (Phila Pa 1976). 1992;17(8 Suppl):S235-43.

4. Lebwohl NH, Cunningham BW, Dmitriev A, Shimamoto N, Gooch L, Devlin V, et al. Biomechanical comparison of lumbosacral fixation techniques in a calf spine model. Spine (Phila Pa1976). 2002;27(21):2312-20

5. Emami A, Deviren V, Berven S, Smith JA, Hu SS, Bradford DS. Outcome and complications of long fusions to the sacrum in adult spine deformity: Luque-Galveston, combined iliac and sacral screws, and sacral fixation. Spine (Phila Pa 1976). 2002:27(7):776-86.

6. Kim YJ, Bridwell KH, Lenke LG, Cho KJ, Edwards CC 2and, Rinella AS. Psudoarthrosis in adult spinal deformity following multisegmental instrumentation and arthrodesis. J Bone Joint Surg Am. 2006;88(4):721-8.

7. KukloTR, Bridwell KH, Lewis SJ, Baldus C, Blanke K, Iffrig T, et al. Minimum 2-year analysis of sacropelvic fixation and L5-S1 fusion using S1 iliac screws. Spine (Phila Pa 1976). 2001;26(18):1976-83.

8. FingerT, Bayerl S, Onken J, Czabanka M, Woitzik J, Vajkoczy P. Sacropelvic Fixation versus fusion to the sacrum for spondylodesis in multilevel degenerative spine disease. Eur Spine J. 2014;23(5):1013-20.

9. Olgilvie JW, Transfeldt EE, Wood KB. Overview of fixation to the sacrum and pelvis in spinal surgery. In: Margulies JY, Floman Y, Farcy JPC, Neuwirth MG, editors. Lumbosacra and Spinopelvic Fixation. 1st ed. Philadelphia: Lippincott-Raven; 1996. p.191-8.

10. Hyun SJ, Rhim SC, Kim YJ, Kim YB. A Mid-term follow-up result of spinopelvic fixation using iliac screws for lumbosacral fusion. J Korean Neurosurg Soc. 2010;48(4):347-53.

11. Kostuik JP. Spinopelvic fixation. Neurol India. 2005;53(4):483-8.

12. Moshifar A, Rand FF Sponseller PD, Parazin SJ, Khanna AJ, Kebaish KM. Pelvic fixation in spine surgery. Historical overview, indications, biomechanical relevance and current techniques. J Bone Joint Surg Am. 2005;87(Suppl2):89-106.

13. Kebaish KM. Sacropelvic fixation: techniques and complications. Spine (Phila Pa 1976). 2010;35(25):2245-51.

14. Peelle MW, Lenke LG, Bridwell KH, Sides B. Comparison of pelvic fixation techniques in neuromuscular spinal deformity correction: Galveston rod versus iliac and lumbosacral screws. Spine (Phila Pa 1976). 2006;31:2392-8.

15. Guler UO, Cetin E, Yaman O, Pellise F, Casademut AV, Sabat MD, et al. Sacropelvic fixation in adult spinal deformity (ASD); a very high rate of mechanical failure. Eur Spine J. 2015;24(5):1085-91.

16. O'Shaughnessy BA, Lenke LG, Bridwell KH, Cho W, Zebala LP, Chang MS, et al. Should symptomatic iliac Screws be electively removed in adult spinal deformity patients fused to the sacrum? Spine (Phila Pa 1976). 2012:37(13):1175-81.

17. Tsuchiya K, Bridwell KH, Kuklo TR, Lenke LG, Baldus C. Minimum 5-Year Analysis of L5-S1 fusion using sacropelvic fixation (bilateral S1 and iliac screws) for spinal deformity. Spine (Phila Pa 1976). 2006;31(3):303-8.

18. Tumialán LM, Mummaneni PV. Long-segment spinal fixation using pelvic screws. Neurosurgery. 2008;63(3 Suppl):183-90 